\title{
An investigation of the effects of intravenous administration of thiomolybdate on copper metabolism in chronic $\mathrm{Cu}$-poisoned sheep
}

\author{
By S. R. GOONER.ATNE, J. MCC. HOWELL AND J. M. GAWTHORNE \\ Division of Veterinary Biology, School of Veterinary Studies, Murdoch University, \\ Murdoch, Western Australia 6150, Australia
}

(Received 1 April 1980-Accepted 3 June 1981)

\begin{abstract}
1. Fourteen sheep were dosıd repeatedly with a solution of copper sulphate $(2 \mathrm{~g} / \mathrm{l})$ in order to induce chronic copper poisoning and four similar undosed animals acted as controls.

2. Thiomolybdate (TM) was intravenously administered to all control sheep and to all except two of the test sheep. A variety of biochemical factors were studied before and after injections of TM.

3. The direct-reacting $\mathrm{Cu}$, whole-blood $\mathrm{Cu}$ and plasma $\mathrm{Cu}$ concentrations were elevated in animals given TM injections and at the 'haemolytic crisis' of untreated chronic $\mathrm{Cu}$-poisoned animals. But most of the increased $\mathrm{Cu}$ observed on injecting TM was insoluble in trichloroacetic acid (TCA) and did not enter erythrocytes. The results indicate that uptake of $\mathrm{Cu}$ by erythrocytes is essential for haemolysis to occur and that for this to happen the $\mathrm{Cu}$ must be in a direct reacting, TCA-soluble form.

4. Increased amounts of $\mathrm{Cu}$ 'were excreted in the urine at haemolysis and at the commencement of TM injections. High levels of direct-reacting $\mathrm{Cu}$ were found in plasma at these times.

5. Marked changes were not found in caeruloplasmin activity, packed cell volume or the osmotic fragility of erythrocytes except at haemolysis. TM injections did not alter these factors in any of the sheep studied.
\end{abstract}

Haemolysis is the most characteristic symptom of chronic copper poisoning in sheep and is known to be associated with increased blood and tissue $\mathrm{Cu}$ levels, and with liver and kidney damage (Todd, 1969; Ishmael et al. 1971, 1972; Howell, 1978). Several workers (Ross, 1966; Hogan et al. 1968; Kline et al. 1971) have used dietary supplements of molybdenum and sulphate as $\mathrm{Cu}$ antagonists to reduce the toxicity of $\mathrm{Cu}$ to sheep. It has been shown that thiomolybdate (TM), an inorganic compound containing Mo and sulphur, when injected intravenously lowered liver $\mathrm{Cu}$ levels, prevented chronic $\mathrm{Cu}$ poisoning and was of value in the treatment of animals that had developed a haemolytic crisis (Gooneratne et al. 1981). TM did not appear to cause any harmful effects on animal tissues. Although TM appears to be antagonistic to $\mathrm{Cu}$ utilization and is capable of lowering liver $\mathrm{Cu}$ levels the mechanism by which it prevents haemolysis in sheep is not understood.

It is difficult to identify specific sites for the $\mathrm{Cu}-\mathrm{Mo}-\mathrm{S}$ interaction because interactions located in the gut and those in the tissues are related (Dick et al. 1975). El Gallad et al. (1977) discussed the changes in trichloroacetic acid (TCA)-soluble and -insoluble fractions of $\mathrm{Cu}$ in the plasma of sheep given TM intravenously. They observed all $\mathrm{Cu}$ to be in the TCA-insoluble fraction : 5 min after injection of TM but the amount of $\mathrm{Cu}$ in the TCAsoluble fraction increased with time until after $144 \mathrm{~h}$ all $\mathrm{Cu}$ in plasma was TCA-soluble. There is at present insuficient experimental evidence with regard to the influence of TM on the $\mathrm{Cu}$ metabolism of ruminants but a considerable amount of work has been done in animals given dietary Mc supplements in which, presumably, TM was formed in the rumen (Dick et al. 1975). Several workers (Smith et al. 1968; Marcilese et al. 1969) have reported a decrease in caeruloplasinin $(\mathrm{Cp})$ synthesis in sheep given oral Mo supplements. This could result from a decrease in the supply of absorbable $\mathrm{Cu}$ due to its interaction with TM in the rumen rather than due to a direct effect on $\mathrm{Cp}$ synthesis in the liver. Mo supplementation increased the direct-reacting (DR) fraction of plasma Cu (Suttle \& Field, 1968; Marcilese et al. 1969) but $\mathrm{Cp}$ and $\mathrm{DR} \mathrm{Cu}$ do not account for all of the $\mathrm{Cu}$ in the blood of these animals 


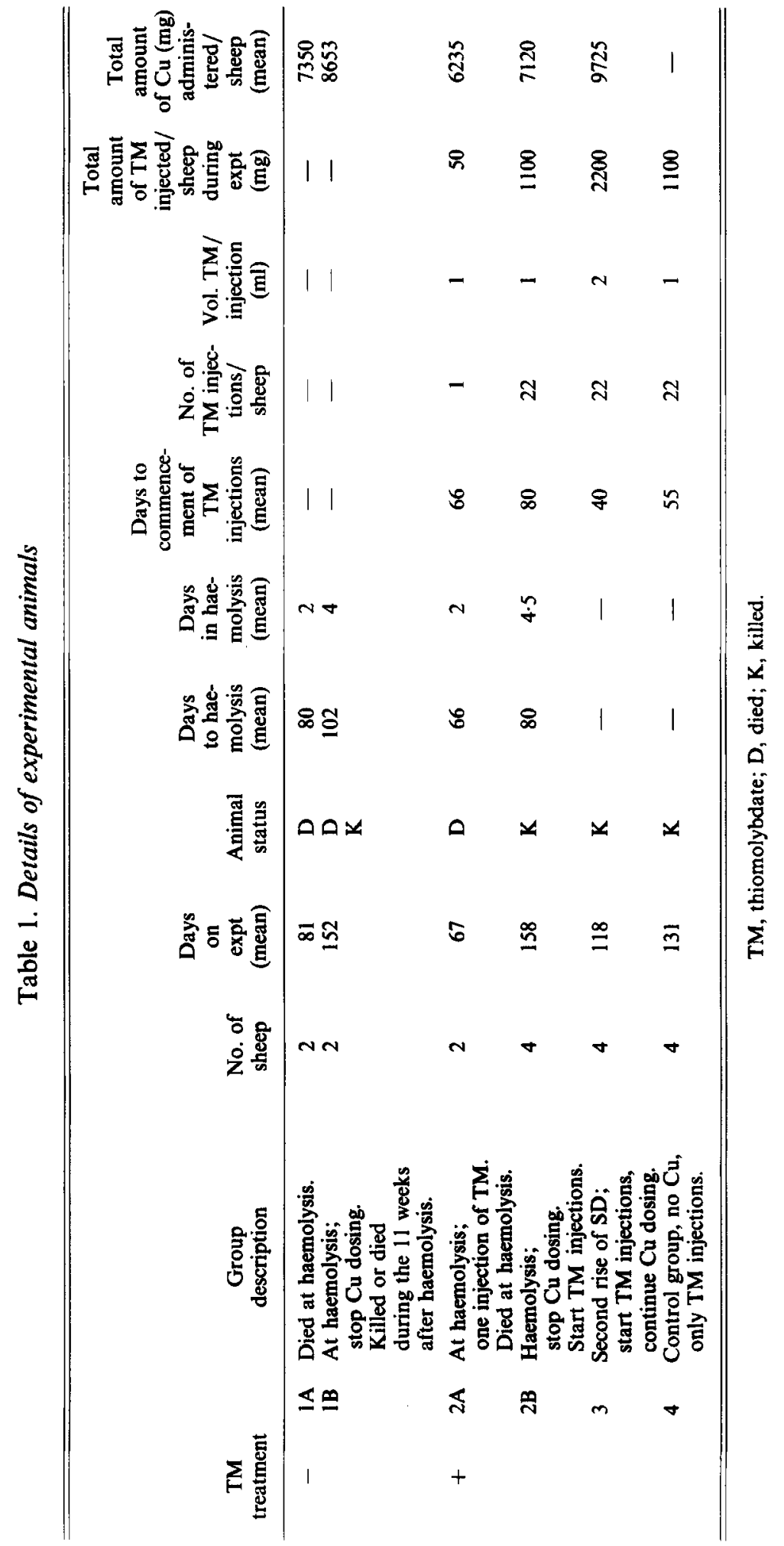


(Smith et al. 1968; Suttle \& Field, 1968). In addition to the changes in blood and plasma, the urinary excretion of $\mathrm{Cu}$ was also increased in animals given Mo supplementation (Rys et al. 1963; Smith et al. 1968; Marcilese et al. 1970).

The changes in liver $\mathrm{Cu}$, plasma $\mathrm{Cu}, \mathrm{Cp}$ synthesis and urinary excretion of $\mathrm{Cu}$ reported in the literature indicate that body $\mathrm{Cu}$ stores are mobilized and excreted in sheep given dietary Mo supplements. The effects of Mo may be mediated via the formation of TM in the rumen and its absorption into the bloodstream (Dick et al. 1975). If so, similar effects might be observed in animals given TM intravenously.

In the present investigation a variety of biochemical factors were studied before and after injections of TM to control sheep and to sheep in various stages of chronic $\mathrm{Cu}$ poisoning. It was hoped that the results might provide an understanding of the possible mechanisms associated with $\mathrm{Cu}$ transfort before and at haemolysis, and the mechanisms involved in the prevention of haemolysis by intravenous administration of TM.

\section{MATERIALS AND METHODS}

Animals

A total of eighteen animals were used in this study. The procedures for housing, feeding and treating these animals have previously been reported (Gooneratne et al. 1981).

The animals were divided into four groups with four to six animals in each group. All sheep except those in group 4 were dosed with a solution of $\mathrm{CuSO}_{4} \cdot 5 \mathrm{H}_{2} \mathrm{O}(2 \mathrm{~g} / \mathrm{l})$. The dosage of TM to be injected into sheep of varying $\mathrm{Cu}$ status had been determined in a previous study (Gooneratne et al. 1981). The details of the animals used in the present study are given in Table 1 and in Gooneratne et al. (1981).

Six of the eighteen sheep, one each from groups 1A, 1B and 2A, 2 each from groups 2B, 3 and 4 were housed individually in fibre-glass metabolism cages for collection of urine.

\section{Collection of blood}

Blood samples were collected from the jugular vein into heparinized containers, 2 weeks before and at the start of the experiment, then twice weekly until all sheep in group 3 had a second rise of plasma sorbitol dehydrogenase (SD) level and thereafter at weekly intervals. At haemolysis blood was collected more frequently. Blood was collected before and $24 \mathrm{~h}$ after each of the first three injections of TM and thereafter before and after every other (odd number) injection. A $24 \mathrm{~h}$ post-injection period for collection of blood was selected as described by El Gallad et al.(1977); the highest concentration of $\mathrm{Cu}$ in plasma after a TM injection was found at this time.

\section{Collection of urine}

Faecal collection bags viere attached to the sheep in metabolism cages to prevent contamination of urine which was collected into washed polyethylene bottles placed at the 'flow out' opening in the bottom of the cage. Samples of urine were taken once every week starting from the first day of $\mathrm{Cu}$ dosing, until sheep had either a 'haemolytic crisis' or the first injection of TM. From then onwards $24 \mathrm{~h}$ samples were taken throughout the period of haemolysis or after each of the first two injections of TM or both and thereafter $24 \mathrm{~h}$ samples were taken after each 'odd-numbered' injection.

\section{Analytical techniques}

$\mathrm{Cu}$. Cu analysis was performed on whole blood (WB) from all sheep as described by Ishmael et al. (1972). Plasma Cu wis estimated by the method of Suttle (1974). Cu in the TCA-soluble fraction of plasma was determined as described by Smith \& Wright (1975a). DR Cu was measured by the method of Suttle \& Field (1968). 
S. R. Gooneratne, J. McC. Howell and J. M. Gawthorne

8
5
5
5
5
5
5

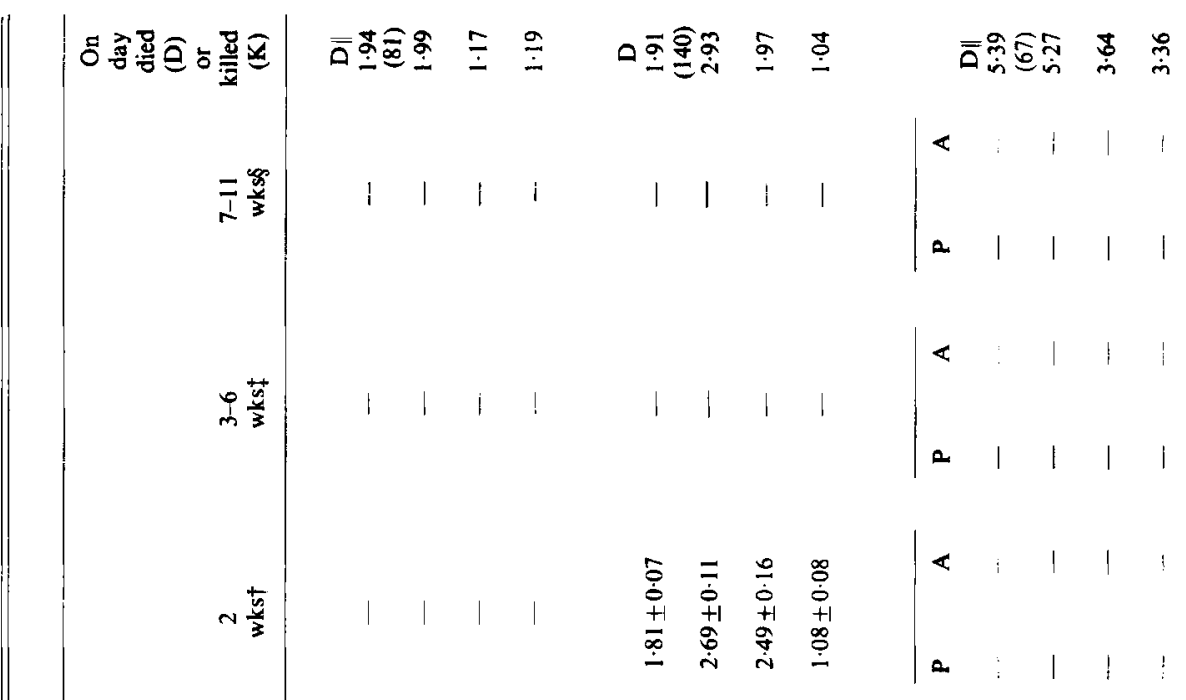

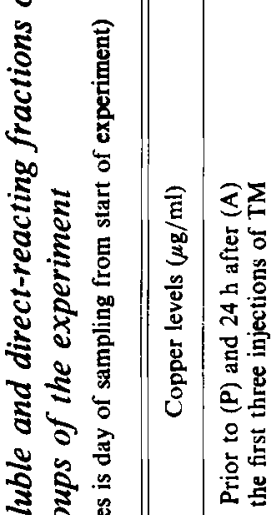

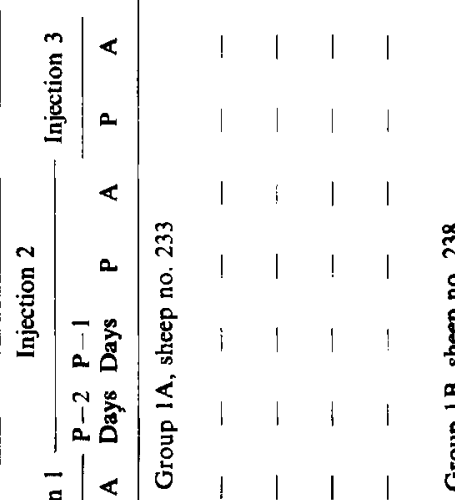

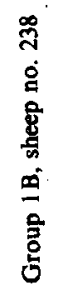

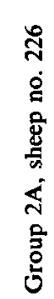

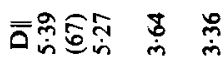

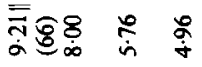

है

हี

รี

2

รั้

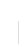

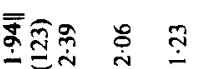

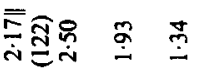

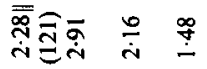

管

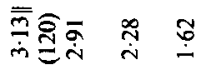

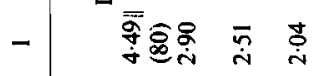

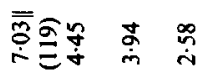

范葛

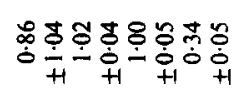

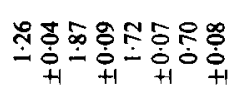

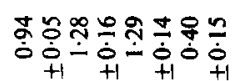

恿。

ํํำ

के

i.

客步

$\stackrel{9}{9}$

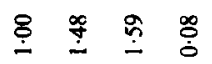

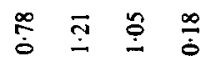

咅

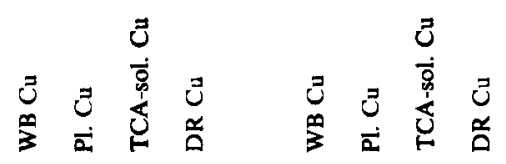

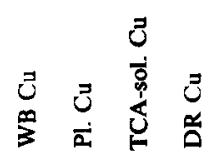




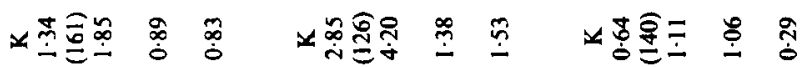

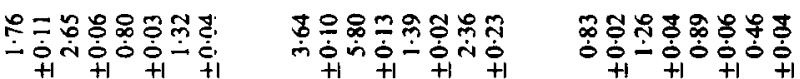

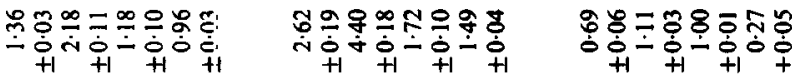

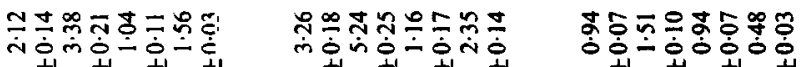

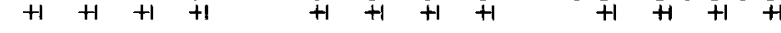

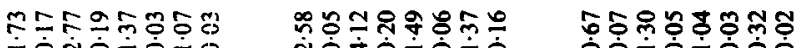

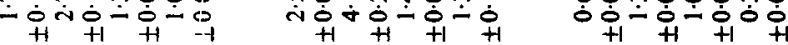

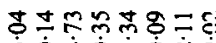

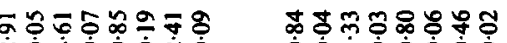

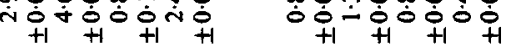

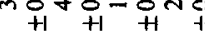

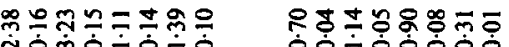

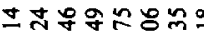

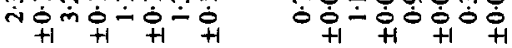

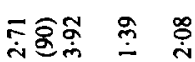

ஸे

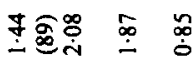

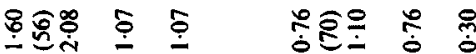

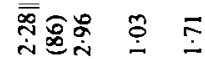

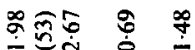

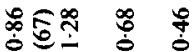

产命京

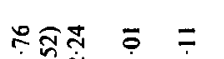

言

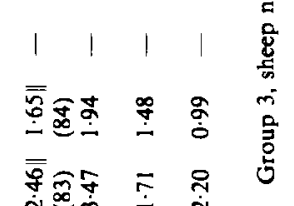

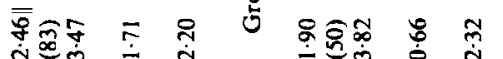

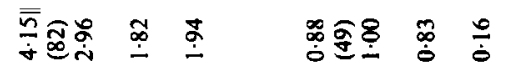

กิ

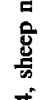

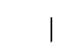

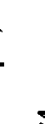

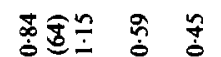

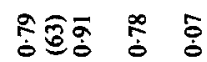

$\dot{\sigma} \dot{f}$

कि

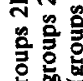

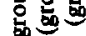

舟牙

굴

드음

wing

毣

nิ들

웡응

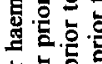

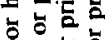

을응

的面五

究宫局言

过粚

늠흥

总

$\sum$

额

害

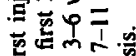

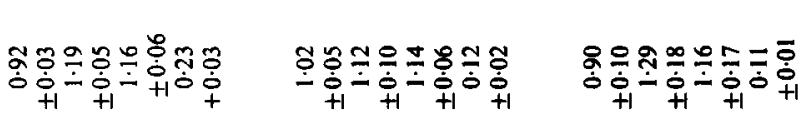

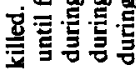

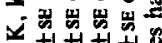

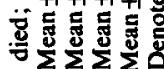

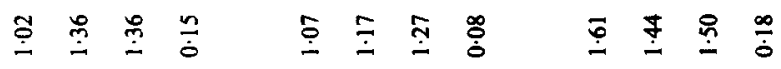

D. $+\ldots+\infty=$

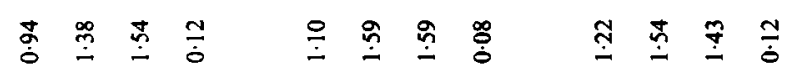

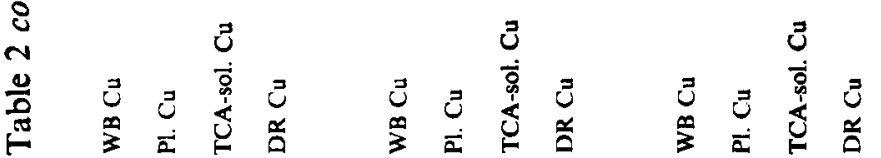


Urine. $\mathrm{Cu}$ analysis was carried out on the urine of all six sheep housed in metabolism cages. Urine $(20 \mathrm{ml})$ was digested with $5 \mathrm{ml}$ concentrated nitric acid, $1 \mathrm{ml}$ concentrated sulphuric acid and $1 \mathrm{ml}$ perchloric acid and the $\mathrm{Cu}$ content of the digest measured using atomic absorption spectrophotometry. The digest mixture of samples collected at haemolysis became frothy and charred with the deposition of a black sediment at the bottom and sides of the flask due to incomplete digestion. Therefore, at haemolysis a lesser volume $(10 \mathrm{ml})$ of urine was taken for digestion and an extra $5 \mathrm{ml}$ concentrated $\mathrm{HNO}_{3}$ was added for complete digestion.

$C p . C p$ estimations were carried out on the six sheep housed in metabolism cages. $\mathrm{Cp}$ was determined by its oxidase activity towards $\rho$-phenylenediamine as described by Smith \& Wright (1974). The results were expressed as International Units.

$S D$. SD activity was measured in plasma as described by Ford (1967).

Packed cell volume (PCV). PCV was determined using a microhaematocrit centrifuge (Hawksley).

Erythrocyte osmotic fragility. Erythrocyte osmotic fragility estimations were carried out on heparinized blood samples from the six sheep housed in metabolism cages by the method described by Schalm et al. (1975). The results were expressed as the concentration of sodium chloride in which $50 \%$ haemolysis occurred.

Urine analysis. Urine was tested for $\mathrm{pH}$, protein, glucose, ketones, bilirubin and haemoglobin using reagent strips (Bili-Labstix; Ames Co.).

Preparation of TM. TM was prepared as described by Gooneratne et al. (1981).

\section{RESULTS \\ Clinical findings}

The details of individual sheep are given in Table 1.

The details of clinical, postmortem and histological findings have already been published (Gooneratne et al. 1981).

\section{$C u$ levels in WB, plasma, TCA-soluble and DR fractions of plasma}

The results for selected sheep are given in Table 2 and Figs. 1-3. The results for all sheep are available elsewhere (Gooneratne, 1979). Until haemolysis or the administration of thiomolybdate, plasma $\mathrm{Cu}$, TCA-soluble $\mathrm{Cu}$ and $\mathrm{WB} \mathrm{Cu}$ remained within normal limits with plasma $\mathrm{Cu} \simeq$ to $\mathrm{TCA}$-soluble $\mathrm{Cu}>\mathrm{WB} \mathrm{Cu}$. In sheep dosed with $\mathrm{Cu}$, beginning at approximately the fourth week of dosing, DR $\mathrm{Cu}$ showed a gradual increase. This increase was most marked one week before haemolysis. In all but one of these sheep that were allowed to proceed to haemolysis (group 1 and 2) the $\mathrm{Cu}$ level in WB and in all fractions of plasma increased sharply at and during haemolysis. In the sheep that were not given TM at haemolysis the increased $\mathrm{Cu}$ levels were in the following descending order WB $\mathrm{Cu}>$ plasma $\mathrm{Cu}>\mathrm{TCA}$-soluble $\mathrm{Cu}>\mathrm{DR} \mathrm{Cu}$. Since $\mathrm{WB} \mathrm{Cu}>$ plasma $\mathrm{Cu}$ it could be inferred that erythrocyte $\mathrm{Cu}$ was increased during haemolysis. Most of the plasma $\mathrm{Cu}$ was TCA-soluble. Once TM was injected a change in this pattern of distribution of $\mathrm{Cu}$ occurred and the increased $\mathrm{Cu}$ levels in the blood stream were in the following descending order, plasma $\mathrm{Cu}>$ WB $\mathrm{Cu}>\mathrm{DR} \mathrm{Cu}>$ TCA-soluble $\mathrm{Cu}$, indicating that erythrocytes $\mathrm{Cu}$ was lower than plasma $\mathrm{Cu}$ and that some of the $\mathrm{DR} \mathrm{Cu}$ was TCA-insoluble. There was also a marked decrease of $\mathrm{Cu}$ in the TCA-soluble fractions. The pattern of distribution of $\mathrm{Cu}$ within the blood stream was similar with each injection of TM irrespective of the experimental group to which the sheep belonged. In samples taken $24 \mathrm{~h}$ after each injection of TM the $\mathrm{Cu}$ levels increased in WB, and in all fractions of plasma except the TCA-soluble fraction in which the $\mathrm{Cu}$ level decreased. Thereafter the level of $\mathrm{Cu}$ in $\mathrm{WB}$ and in fractions of plasma except TCA-soluble, decreased slowly, only to rise again at each TM injection. 


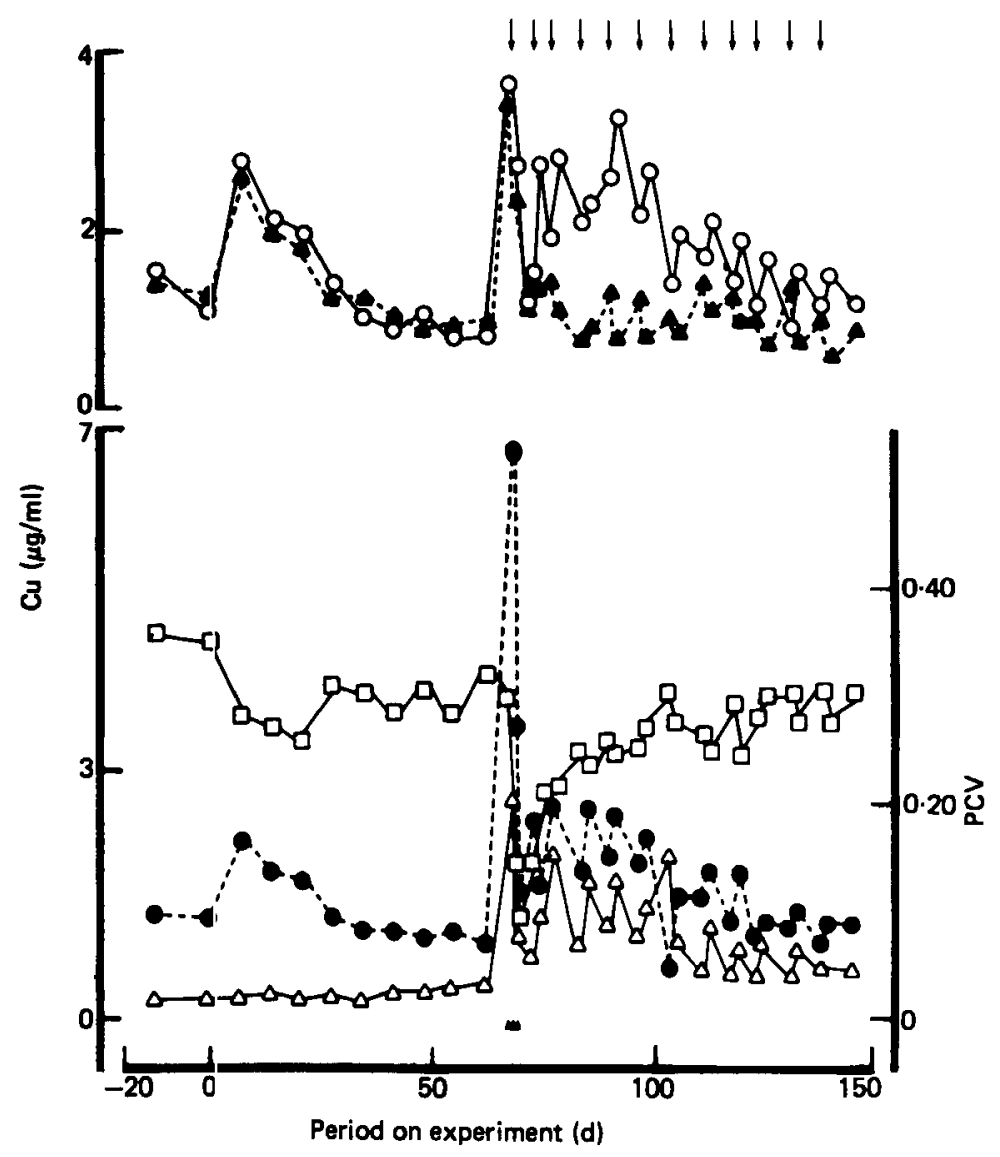

Fig. 1. Whole-blood (O---O), plasma (O-O), plasma trichloroacetic acid(TCA)-soluble (A- - - $\mathbf{A})$ and direct-reacting $(\triangle-\triangle)$ sopper levels and packed cell volume (PCV) $\square-\square$ ) of sheep no. 230 (group 2B) measured throughout the course of the experiment. On the first day of haemolysis before the start of TM injections, $\mathrm{Cu}$ in all fractions increased with the peak level in WB. $\downarrow$, TM injections. $\Delta \Delta \Delta$, days of haemolysis.

In the latter part of the experiment $\mathrm{Cu}$ levels in blood were gradually declining and this was most marked in the sheep which received TM injections but not $\mathrm{Cu}$ (group 4).

\section{$C p$}

The levels of $\mathrm{Cp}$ were most variable with a range of 55-174 IU. Marked fluctuations were seen even between consecutive measurements but these could not be related to the TM injections. The only consistent change observed was the gradual decline in $\mathrm{Cp}$ at a fairly regular rate in sheep of group 4 and this was quite marked in sheep number 229.

\section{PCV}

In all groups of sheep a clecline in PCV was recorded during the first 3-4 weeks of the experiment (Figs. 1, 2, 3). From then onwards the levels tended to fluctuate throughout the course of the experiment except at haemolysis when a marked fall in PCV was recorded (Fig. 1). Following the haemolytic crisis PCV slowly returned to normal levels irrespective of whether the animals reseived TM or not. 


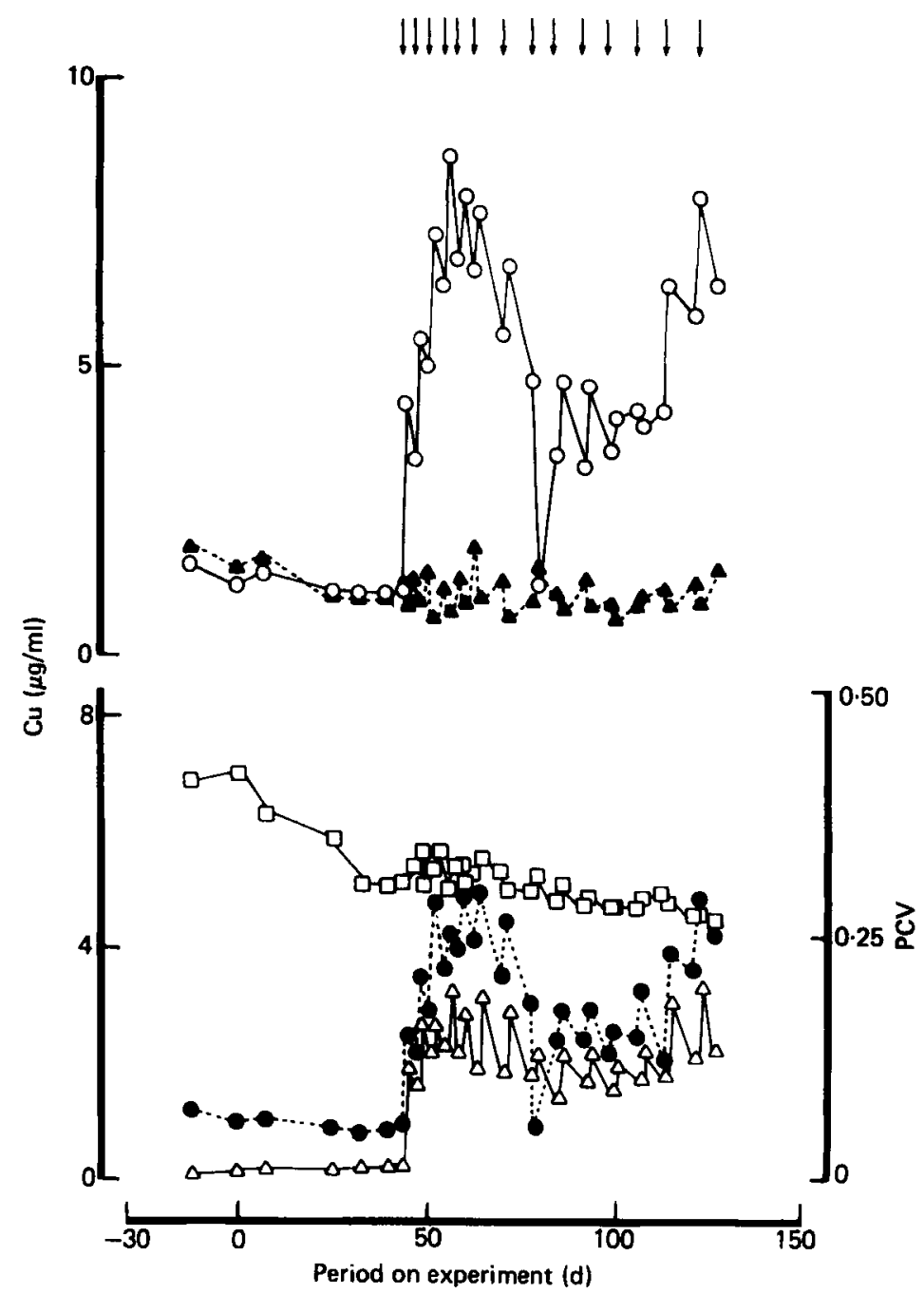

Fig. 2. Whole-blood (O- - $)$, plasma $(O-O)$, plasma trichloroacetic acid(TCA)-soluble $(\triangle---\triangle)$ and direct-reacting $(\Lambda-A)$ copper levels and packed cell volume (PCV) $(\square-\square)$ of sheep no. 225 (group 3) measured throughout the course of the experiment. $\downarrow$, TM injections.

\section{Erythrocyte osmotic fragility}

The measurements of the $50 \%$ lysis point of erythrocytes of sheep at the commencement of the experiment, varied from a concentration of $6 \cdot 1-7.6 \mathrm{~g} \mathrm{NaCl} / 1$. At the onset of haemolysis osmotic fragility increased appreciably. Measurements taken 1 week after the cessation of haemolysis indicated a decrease of osmotic fragility. These levels were even lower than those observed before the start of the experiment. The TM injections did not appear to alter the osmotic fragility in any of the sheep studied.

\section{Urinary $\mathrm{Cu}$}

The most marked change observed was a 4-7-fold increase in concentration of $\mathrm{Cu}$ as well as an increase in $\mathrm{Cu}$ excreted/24 $\mathrm{h}$ in the urine collected during the period before haemolysis. 


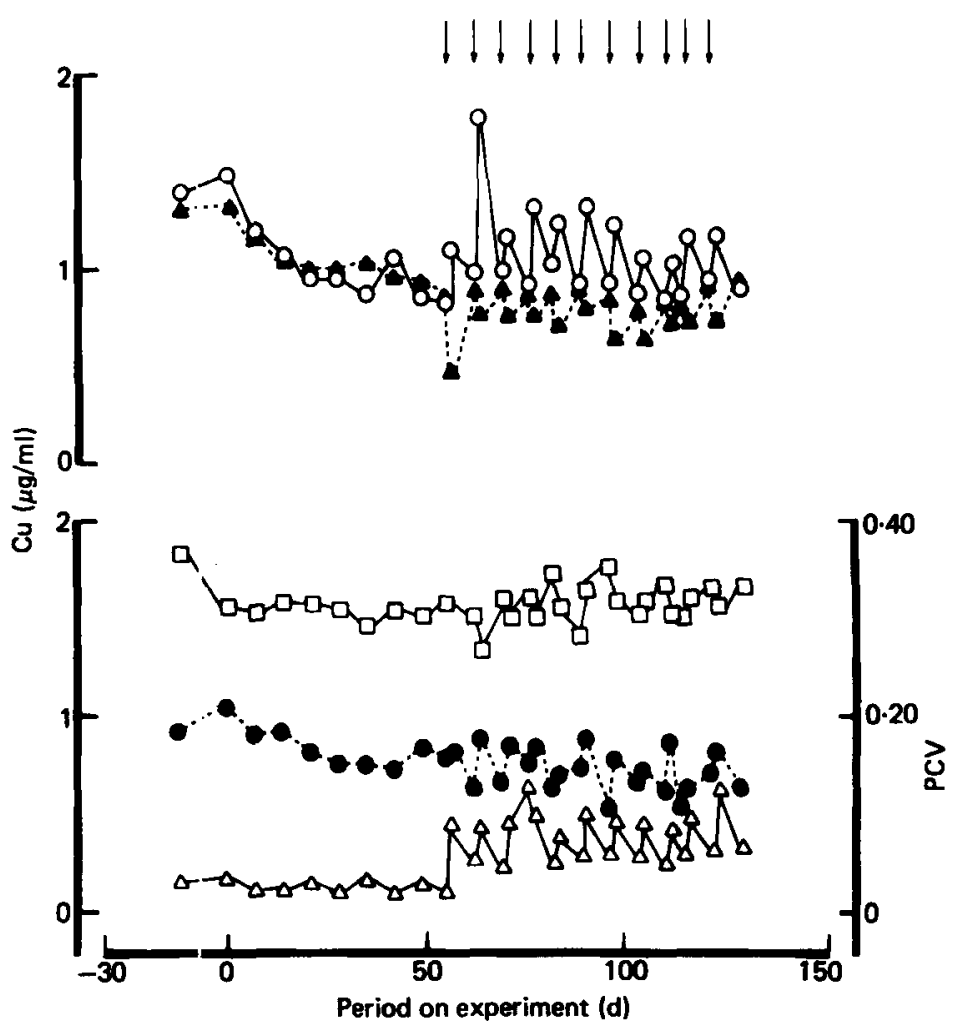

Fig. 3. Whole-blood (O- - D), plasma $(\mathrm{O}-\mathrm{O})$, plasma trichloroacetic acid(TCA)-soluble $(\triangle---\triangle)$ and direct-reacting ( $\Delta-\Delta)$ copper levels and packed cell volume (PCV) ( $\square-\square)$ of sheep no. 229 (group 4) measured throughout the course of the experiment. $\downarrow$, TM injections.

These rose from a mean of $0.45 \mu \mathrm{g} / \mathrm{ml}$ and $180 \mu \mathrm{g} / 24 \mathrm{~h}$ respectively in the first week of the experiment to $1.16 \mu \mathrm{g} / \mathrm{ml}$ and $1067 \mu \mathrm{g} / 24 \mathrm{~h}$ in the week prior to haemolysis. Urinary $\mathrm{Cu}$ was markedly increased during the periods of haemolysis with a mean of $2315 \mu \mathrm{g} / 24 \mathrm{~h}$. These increases were mostly due to an increase in the concentration of $\mathrm{Cu}$ in urine (mean $4.71 \mu \mathrm{g} / \mathrm{ml}$ ) although at times the volume excreted was also greater. TM injections only increased the $\mathrm{Cu}$ concentration in urine in sheep which were continuously dosed with $\mathrm{Cu}$ (group 3). These levels rose from $0.30 \mu \mathrm{g} / \mathrm{ml}$ at the start of the experiment to $1.63 \mu \mathrm{g} / \mathrm{ml}$ at its termination.

\section{Urine analysis}

$p H$. Values for sheep in all groups varied from 6 to 8 , until haemolysis when it became more acidic ( $\mathrm{pH} \mathrm{5-6).} \mathrm{The} \mathrm{pH}$ returned to normal once the crisis was over.

Glucose and ketones. These compounds were not detected in any of the samples of urine collected.

Protein. Never more than a trace of protein was found in urine of any sheep until the 2nd or 3rd day of haemolysis when the levels rose to as much as $1000 \mathrm{mg} / \mathrm{l}$ but returned to normal once the crisis 'vas over.

Bilirubin. Bilirubin was absent in samples of urine taken before haemolysis but appeared 
during the periods of haemolysis. Bilirubin was detected only in red-tinged urine and could not be detected in urine of normal colour.

Haemoglobin. The presence of haemoglobin in urine, could not be detected until, or, in one sheep, on the day before haemolysis. In the latter sheep (no. 238) a sample of urine taken $1 \mathrm{~d}$ before haemolysis was of normal colour but was positive for blood.

\section{DISCUSSION}

The changes of $\mathrm{Cu}$ levels in blood and plasma presented here are similar to those reported in sheep given dietary supplements of $\mathrm{Mo}$ and $\mathrm{SO}_{4}$ (Dick, 1956; Suttle \& Field, 1968; Smith et al. 1968; Marcilese et al. 1969, 1970; Smith \& Wright, 1975a, b). Hence it could be assumed that jugular infusion of TM adequately simulates the post-absorptive supply of Mo and S possibly in the form of TM (Dick et al. 1975). But since a large dose was rapidly administered directly into the systemic circulation a much greater response than previously recorded was seen. This was especially so in the concentration of $\mathrm{Cu}$ in WB and different fractions of plasma.

Before the start of injections of TM, the levels of $\mathrm{Cu}$ in WB, plasma, and TCA-soluble fraction were within normal limits in all sheep. But the level of DR Cu of sheep dosed with $\mathrm{Cu}$ was at least twice that of the animals in group 4 which did not receive $\mathrm{Cu}$. Before the injection of TM the $\mathrm{Cu}$ excreted in the urine was much greater in sheep dosed with $\mathrm{Cu}$ than in the control animals of group 4, this difference being most marked in sheep near to the haemolytic crisis, indicating the possibility that at least a part of the DR Cu was ultrafilterable. Several groups of workers have reported that $\mathrm{Cu}$ in the DR fraction is in a loosely-bound form and some of it may be ultrafilterable (Gubler et al. 1953; Gaballah et al. 1965; Smith et al. 1968; Marcilese et al. 1969). If this is so the increased amounts of $\mathrm{Cu}$ excreted in urine at haemolysis and after commencement of TM injections could also be due to the very high levels of DR Cu found in plasma during this time. The increase in the amount of $\mathrm{Cu}$ excreted in urine after the commencement of TM injections was due to an increase in the concentration of $\mathrm{Cu}$ in urine as well as an increase in the volume of urine. Similar results were observed in a preliminary investigation, where we observed that TM injections increased excretion of $\mathrm{Cu}$ in urine but not in faeces (Gooneratne, 1979). This result is in agreement with the findings of Marcilese et al. (1970) who gave sheep Mo and $\mathrm{SO}_{4}$ in the diet.

It has been shown that for 1 or $2 \mathrm{~d}$ before the haemolytic crisis plasma $\mathrm{Cu}$ is greatly increased and far exceeds WB Cu and erythrocyte $\mathrm{Cu}$ levels (Ishmael et al. 1972). It has also been shown that an increase in erythrocyte $\mathrm{Cu}$ occurs at least $24 \mathrm{~h}$ before haemolysis (Ishmael et al. 1972; Gooneratne \& Howell, 1980) indicating that the excess Cu that was present in plasma before haemolysis had entered erythrocytes. This excess of $\mathrm{Cu}$ in the erythrocytes directly contributes to haemolysis. In the present study, irrespective of this group to which the sheep belonged, each injection of TM increased plasma $\mathrm{Cu}$ to very high levels, but this $\mathrm{Cu}$ did not enter the erythrocytes possibly because most of it was TCA-insoluble. It has been shown by Bremner (1976) that $\mathrm{Cu}$ is firmly bound to this novel protein fraction, in which $\mathrm{Cu}$ and $\mathrm{Mo}$ are closely associated. It has been proposed by several workers (McCosker, 1968; Ishmael et al. 1972) that in chronic $\mathrm{Cu}$ poisoning the release of $\mathrm{Cu}$ from the liver into the bloodstream is followed by an uptake of $\mathrm{Cu}$ by the erythrocytes, and that it is necessary for a high concentration of blood $\mathrm{Cu}$ to be maintained for $24-48 \mathrm{~h}$ in order to cause haemolysis (Todd \& Thompson, 1964). Howell \& Gopinath (1977) found that haemolysis occurred after four daily injections of $\mathrm{CuSO}_{4}$ giving the daily equivalent of $20 \mathrm{mg}$ $\mathrm{Cu}$. This is a similar result to that obtained by Todd \& Thompson (1964) using Cu acetate. 
However, Ishmael \& Gopinath (1972) found that haemolysis occurred within $24 \mathrm{~h}$ of a single intravenous injection of $50 \mathrm{mg} \mathrm{Cu}$ given as $\mathrm{CuSO}_{4}$. The WB and plasma Cu content of these sheep was quickly and markedly elevated. Erythrocyte $\mathrm{Cu}$ was not measured but $3 \mathrm{~h}$ after injection WB $\mathrm{Cu}$ was greater than plasma $\mathrm{Cu}$ thus indicating an uptake of $\mathrm{Cu}$ by erythrocytes. In our sheep given TM injections, very high concentrations of $\mathrm{Cu}$ in WB and plasma were recorded for long periods of time without haemolysis occurring but this $\mathrm{Cu}$ was not taken up by the erythrocytes. We presume that the presence of excess DR $\mathrm{Cu}$ in a TCA-soluble form in plasma rather than an increase in total plasma $\mathrm{Cu}$ would be responsible for the increased uptake of $\mathrm{Cu}$ by erythrocytes that occurs in untreated sheep at the time of the haemolyiic crisis. The ability of TM to increase WB and plasma Cu without initiating haemolysis simulates the in vitro studies of Goldberg et al. (1956) that were confirmed by Thompson \& Todd (1976) who found that haemolysis only occurred when large amounts of $\mathrm{Cu}(750 \mathrm{mg} / \mathrm{l})$ were added to erythrocytes in plasma. Hence it could be assumed that it is not the increase in WB Cu per se but the increase in DR Cu present in a TCA-soluble form which predisposes erythrocytes to take up more $\mathrm{Cu}$ and undergo lysis.

In the present study $\mathrm{Cp}$ levels were variable. It has been shown in rabbits (Gahallah et al. 1965) that high levels of $\mathrm{Mo}$ and $\mathrm{SO}_{4}$ in the diet resulted in a decreased uptake of $\mathrm{Cu}$ and an inhibition of $\mathrm{Cp}$ synthesis. Mills et al. (1978) observed similar results when giving TM to rats; $2 \mu \mathrm{g} \mathrm{Mo,} \mathrm{as} \mathrm{TM/g} \mathrm{diet} \mathrm{was} \mathrm{offered} \mathrm{to} \mathrm{rats} \mathrm{for} 5$ weeks in a diet containing $3 \mu \mathrm{g} \mathrm{Cu} / \mathrm{g}$. In these animals liver $\mathrm{Cu}$ stores were decreased by $30 \%$ and plasma $\mathrm{Cp}$ by $60 \%$. On increasing the amount of Mo to $4 \mu \mathrm{g} / \mathrm{g}$ diet, liver $\mathrm{Cu}$ was decreased by $50 \%$ and this concentration of Mo completely abolished the $\mathrm{Cp}$ activity in plasma. Although the Cu levels in the livers of sheep given TM in the present experiment were decreased by up to $60 \%$ (Gooneratne et al. 1981), its effect on plasma $\mathrm{Cp}$ was minimal. Similar results have been published for sheep by Smith \& Wright (1975b) who did not observe a change in the absolute concentration of $\mathrm{Cp}$ when the diet was supplemented by $\mathrm{Mo}$ and $\mathrm{SO}_{4}$. It appears from the present study that in sheep, liver $\mathrm{Cu}$ stores have to be greatly reduced before $\mathrm{Cp}$ synthesis is affected. However, Marsilese et al. (1969) observed a decrease in the $\mathrm{Cp} \mathrm{Cu}$ levels in sheep given $\mathrm{Mo}$ and $\mathrm{SO}_{4}$, but the levels reported by these authors may have been an underestimation as they assumed $\mathrm{Cp} \mathrm{Cu}$ to represent the difference between total plasma $\mathrm{Cu}$ and $\mathrm{DR} \mathrm{Cu}$. Studies of the distribution of $\mathrm{Cu}$ in the plasma of Mo-supplemented sheep and guinea-pigs have shown that $\mathrm{Cp}$ and. $\mathrm{DR} \mathrm{Cu}$ do not account for all of the plasma $\mathrm{Cu}$ (Suttle \& Field, 1968; Smith et al. 1968). The occurrence of a non- $\mathrm{Cp}$ and non-albumin $\mathrm{Cu}$ has been demonstrated (Bremner $\& \varepsilon$ Young, 1978). This residual $\mathrm{Cu}$ fraction precipitated by TCA contains both Mo (Smith \& Wright, 1975b) and protein (Smith \& Wright, 1974, 1975a). The origin and metabolic significance of this fraction is yet to be established.

Marked changes in PCV were not seen in any sheep except at haemolysis when levels as low as $9 \%$ were observad. PCV of sheep in groups $1 \mathrm{~B}$ and $2 \mathrm{~B}$ returned to normal levels 2-3 weeks after haemolysis. TM did not appear to have any adverse effect on the erythropoetic activity.

The osmotic fragility measurements on erythrocytes give an assessment of the permeability and stability of erythrocyte membranes and also reflect their ability to take up water without lysis. It has been known for many years that heavy metals affect erythrocyte fragility (Lessler \& Walters, 1973). The only report on the osmotic fragility measurements on chronic Cu-poisoned sheep (Froslie \& Norheim, 1976) gave levels $20 \mathrm{~d}$ before and at haemolysis but failed to report on the levels during the most critical period immediately before haemolysis. In the presejt study, although weekly measurements were made, marked changes were not observed except at haemolysis, when osmotic fragility was increased. Osmotic fragility was still within normal limits 1 week before haemolysis. Adams et al. (1979) 
observed a similar increase in osmotic fragility without haemolysis on incubating erythrocytes in $0.60 \mathrm{mM}^{-\mathrm{CuSO}_{4}}$ solution. The administration of TM did not appear to affect the permeability of erythrocytes.

\section{REFERENCES}

Adams, K. F., Johnson, H. Jr., Hornowski, K. E. \& Lineberger, T. H. (1979). Biochim. Biophys. Acta. 550, 279.

Bremner, I. (1976). Proc. Nutr. Soc. 35, 21 A.

Bremner, I. \& Young, B. W. (1978). Br. J. Nutr. 39, 325.

Dick, A. T. (1956). Soil Sci. 81, 229.

Dick, A. T., Dewey, D. W. \& Gawthorne, J. M. (1975). J. agric. Sci., Camb. 85, 567.

El-Gallad, T. T., Bremner, I. \& Mills, C. F. (1977). Proc. Nutr. Soc. 36, 105A.

Ford, E. J. H. (1967). J. Comp. Path. Ther. 77, 405.

Froslie, A. \& Norheim, G. (1976). Acta Vet. scand. 17, 307.

Gaballah, S., Abood, L. G., Kapsalis, A. \& Sturdivant, D. (1965). Proc. Soc. exp. Biol. Med. 119, 625.

Goldberg, A., Williams, C. G., Jones, R. S., Yanagita, M., Cartwright, G. E. \& Wintrobe, M. M. (1956). J. Lab. clin. Med. 48, 442 .

Gooneratne, S. R. (1979). Morphometric, electron microscopic, biochemical and pathological investigation of liver of normal and copper poisoned sheep. Ph D Thesis, Murdoch University, Western Australia.

Gooneratne, S. R. \& Howell, J. McC. (1980). Res. vet. Sci. 28, 351.

Gooneratne, S. R., Howell, J. McC. \& Gawthorne, J. M. (1981). Br. J. Nutr. 46, 457.

Gubler, C. J., Lahey, M. E., Cartwright, G. E. \& Wintrobe, M. M. (1953). J. clin. Invest. 32, 405.

Hogan, K. G., Money, D. F. L. \& Blayney, A. (1968). N. Z. Jl agric. Res. 11, 135.

Howell, J. McC. (1978). In The Proceedings of the 3rd International Symposium on Trace Element Metabolism in Man and Animals, p. 536 [M. Kirchgessner, editor]. Weihenstephan: Arbeitskreis für Tierernahrungsforschung. Howell, J. McC. \& Gopinath, C. (1977). Res. vet. Sci. 22, 86.

Ishmael, J. \& Gopinath, C. (1972). J. Comp. Path. Ther. 82, 47.

Ishmael, J., Gopinath, C. \& Howell, J. McC. (1971). Res. vet. Sci. 12, 358.

Ishmael, J., Gopinath, C. \& Howell, J. McC. (1972). Res. vet. Sci. 13, 22.

Kline, R. D., Hays, V. W. \& Cromwell, G. L. (1971). J. Anim. Sci. 33, 771.

Lessler, M. A. \& Waiters, M. J. (1973). Proc. Soc. exp. Biol. Med. 142, 548.

McCosker, P. J. (1968). Res. vet. Sci. 9, 103.

Marcilese, N. A., Ammerman, C. B., Valsecchi, R. M., Dunavant, B. G. \& Davis, G. K. (1969). J. Nutr. 99, 177.

Marcilese, N. A., Ammerman, C. G., Valsecchi, R. M., Dunavant, B. G. \& Davis, G. K. (1970). J. Nutr. $100,1399$.

Mills, C. F., Bremner, I., El-Gallad, T. T., Dalgarno, A. C. \& Young, B. W. (1978). In The Proceedings of the 3rd International Symposium on Trace Element Metabolism in Man and Animals, p. 150 [M. Kirchgessner, editor]. Weihenstephan: Arbeitskreis für Tierernahrungsforschung.

Ross, D. B. (1966). Br. vet. J. 122, 279.

Rys, R. M., Kuklewicz, M. \& Sokol, J. (1963). Roczn Naukro B 83, 145.

Schalm, O. W., Jain, N. C. \& Carroll, E. J. (1975). In Veterinary Haematology, 3rd ed. p. 76. Philadelphia: Lea and Fabiger.

Smith, B. S. W., Field, A. C. \& Suttle, N. F. (1968). J. Comp. Path. Ther. 78, 449.

Smith, B. S. W. \& Wright, H. (1974). Clinica chim. Acta 50, 359.

Smith, B. S. W. \& Wright, H. (1975a). J. Comp. Path. Ther. 85, 299.

Smith, B. S. W. \& Wright, H. (1975b). Clinica chim. Acta 62, 55.

Suttle, N. F. (1974). Br. J. Nutr. 32, 395.

Suttle, N. F. \& Field, A. C. (1968). J. Comp. Path. 78, 351.

Thompson, R. H. \& Todd, J. R. (1976). Res. vet. Sci. 20, 257.

Todd, J. R. (1969). Proc. Nutr. Soc. 28, 189.

Todd, J. R. \& Thompson, R. H. (1964). J. Comp. Path. Ther. 74, 542. 